\section{FEBRUARY MEETINGS}

Feb. 6-11. American Assoc. for the Advancement of Science annual meeting. Chicago, IL. Info: AAAS '92, Meetings Office, $1333 \mathrm{H} \mathrm{St}$. NW, Washington, DC 20005. Tel: 202-3266462 .

Feb. 9-11. 4th annual public affairs conference. Washington, DC. Info: American Council of Independent Laboratories (ACIL), $1629 \mathrm{~K} \mathrm{St.,}$ NW, Ste. 400, Washington, DC 20006. Tel: 202-887-5872.

Feb. 9-13. 4th int'1. symposium on high performance capillary electrophoresis. Amsterdam, the Netherlands. Info: Shirley Schlessinger, Symposium Mgr., HPCE '92, 400 E. Rudolph St., Ste. 1015, Chicago, IL 60601.

Feb. 19-21. 14th annual conference of the biomedical marketing association. Washington, DC. Info: Biomedical Marketing Assoc., 200 Marott Center, 342 Massachusetts Ave., Indianapolis, IN 46204. Tel: 317-237-9100.

Feb. 21. What price innovation? Pharmaceuticals in the era of cost-containment. Philadelphia, PA. Info: 1992 Wharton Health Care Conference, 204 Colonial Penn Center, 3641 Locust Walk, Philadelphia, PA 19104-6218. Tel: 215-898-6861.

Feb. 24-27. Biopharmaceutics: old issues and new controversies. Austin, TX. Info: Division of Pharmaceutics, or Pharmacy Continuing Education, College of Pharmacy, Univ. of Texas at Austin, Austin, TX 78712-1074. Tel: 512$471-1407$ or $512-471-6213$.

Feb. 26-27. Transgenic disease models. San Diego, CA. Info: IBC USA Conferences, 8 Pleasant St., Bldg. D, S. Natick, MA 01760. Tel: 508650-4700.

Feb. 27-29. Progress in vascular biology, hemostasis and thrombosis. La Jolla, CA. Info: Dept. of Academic Affairs, 403C, Scripps Clinic and Research Foundation, 10666 N. Torrey Pines Road, La Jolla, CA 92037. Tel: 619-554-8556.

Feb. 28-Mar. 5. Cell biology of virus entry, replication and pathogenesis. Taos, NM. Info: Keystone Symposia, P.O. Box 2156 , Dillon, CO 80435. Tel: 303-262-1230. Note: This is just one of many Keystone symposia for 1992. For a complete list of symposia, contact Keystone.

\section{MARCH MEETINGS}

Mar. 1-3. Western regional american association of pharmaceutical scientists (AAPS) meeting. Reno, NV. Info: Carol Lambert, Lambert Management Consultants, 831 Oak Knoll Dr., Suite 1200, Lake Forest, IL 60045. Tel: 708295-0045.

Mar. 5-7. 7th int'l. conference on monoclonal antibody immunoconjugates for cancer. San
Diego, CA. Info: Cass Jones, Professional Conference Mgmt., 7916 Convoy Ct., San Diego, CA 92111 . Tel: 619-565-9921.

Mar. 9-13. ISPE/FDA forum. Bethesda, MD. Info: ISPE, 3816 W. Linebaugh Ave., Suite 412, Tampa, FL 33624. Tel: 813-960-2105.

Mar. 17-19. 5th symposium on protein studies and purification. Grenoble, France. Info: G.R.B.P., 45 bis rue des Casseaux, F-91140 Villebon, France. Tel: 033-1-60-10-20-27.

Mar. 20. Patenting life. London. Info: Christine Roberts, GB Biotechnology, 4 Beaconsfield Ct., Sketty, Swansea, SA2 9JU, U.K. Tel:0792-296560.

Mar. 23-25. Pharmacokinetics: new challenges and new technologies in drug development \& regulatory submissions. Basel, Switzerland. Info: Program Division, Technomic Publishing, Missionsstrasse 44, CH-4055 Basel, Switzerland. Tel: 061-43-52-26.

\section{COURSES AND WORKSHOPS}

Feb. 19-21. Getting OTC drugs to market. E. Brunswick, NJ. Info: Center for Professional Advancement, General Info., P.O. Box H, E. Brunswick, NJ 08816-0257. Tel: 908-613-4535.

Feb. 26-27. Consistent mixing: the key to uniform quality. Madison, WI. Info: Dept. of Engineering Professional Development, Univ. of Wisconsin-Madison, 432 N. Lake St., Madison, WI 53706. Tel: 800-462-0876.

Mar. 2-6. Recombinant DNA methodology. Washington, DC. Info: Office Manager, Center for Advanced Training in Cell and Molecular (CATCMB), 103 McCort-Ward, Catholic Univ. of America, Washington, DC 20064. Tel: 202319-5276.

Mar. 2-17. Yeast molecular genetics. Chapel Hill, NC. Info: Dr. Wayne Litaker, Univ. of North Carolina at Chapel Hill, Program in Molecular Biology \& Biotechnology, 101 MBBRL Bldg., CB \# 7100, Chapel Hill, NC 27599-7100. Tel: 919-966-1730.

Mar. 3-4. How to get to market with medical devices and diagnostics. E. Brunswick, NJ. Info: see for Feb. 19-21.

Mar. 5. OSHA laboratory standard. New Orleans, LA. Info: Professional Analytical and Consulting Services (PACS), 409 Meade Dr., Corapolis, PA 15108. Tel: $412-457-6576$ or 800-367-2587. Note: This is the first of many PACS courses offered in New Orleans in March. For a complete listing, contact PACS.

Mar.9-13. Receptor binding techniques. Washington, DC. Info: see for Mar. 2-6.

Mar. 10-13. Fermentation methods and scaleup strategies. University Park, PA. Also June
10-16, and Oct. 13-16. Info: Patricia Phillips, Penn State Biotechnology Inst., 519 Wartik Laboratory, Penn. State Univ., University Park, PA 16802. Tel: 800-833-5533.

Mar. 10-13a. Cell culture and hybridomas: quality control and cryopreservation. Rockville, MD: Info: ATCC/Workshops, 12301 Parklawn Dr., Rockville, MD 20852. Tel: 301-231-5566.

Mar. 23-27. Recombinant DNA methodology. Columbia, MD. Info: Workshop Coordinator, Exon-Intron, 9151 Rumsey Road, Suite 130, Columbia, MD 21045-1929. Tel: 410-730-3984.

Mar. 25. Impact behavior and testing of polymers and composites. Chicago, IL. Info: Michael Roop, Dir. of Educational Services, L.J. Broutman Assoc., 3424 S. State St., Chicago, IL 60616. Tel: 312-842-4100.

\section{EXECUTIVE CHANGES}

Institute for Biological Research and Development (Irvine, CA) named Paul Litka senior vice president, general manager.

Quadra Logic (Vancouver, British Columbia) appointed William Foran president and chief executive officer.

California Biotechnology (Mountain View, CA) named Kenneth Luskey director of diabetes and obesity, and Elliott Grossbard vice president of medical and regulatory affairs.

Quality Biotech (Camden, NJ) announced that Elizabeth White, director of marketing, will head the company's marketing initiatives in 1992.

Biogen (Cambridge, MA) appointed James Mullen vice president-operations, and Amy Seltzer director-investor relations.

Gilead (Foster City, CA) named Howard Jaffe vice president for clinical affairs.

MicroProbe (Garden Grove, CA) appointed Monica Krieger vice president of regulatory affairs and reagent quality assurance.

Pitman-Moore (Mundelein, IL) appointed Elaine Hutten manger, compensation and benefits, and Michael Cain director of commercial product development.

Telios Pharmaceuticals (San Diego, CA) promoted Robert Erickson to president and chief executive officer.

Immunology Limited (Cambridge, U.K.) announced Paul Haycock has joined the company as chief executive officer.

COR Therapeutics (So. San Francisco, CA) appointed Laura Brege to vice president, finance and chief financial officer. 